Poznańskie Studia Teologiczne 29(2015), s. 27-53.

doi: $10.14746 /$ pst.2015.29.3

\author{
Joseph Ellul ${ }^{1}$ \\ University of Malta \\ Msida
}

\title{
Religious discourse and Philosophy Ibn Rušd and Thomas Aquinas
}

In his encyclical letter Fides et Ratio Pope (today Saint) John Paul II wrote of "the fundamental harmony between the knowledge of faith and the knowledge of philosophy". In his words, "faith asks that its object be understood with the help of reason; and at the summit of its searching reason acknowledges that it cannot do without what faith presents."

The relationship between faith and reason is one of the fundamental issues that both philosophers and theologians have had to come to grips with since the first stages of development of speculative thought, especially in those instances where reason came into conflict with the established religious doctrine. Western civilization has known of three major instances that have contributed to a state of equilibrium between faith and reason: (a) the Jewish and early Christian response to Greek thought as formulated by Philo of Alexandria (d. c. 50) and the Apologetic movement initiated by Justin Martyr (d. 165); (b) the approach taken by Augustine (d. 430) to interpreting Platonic and Stoic thought in the light of the Christian faith; and (c) the synthesis of Platonic, Aristotelian, and Neoplatonic thought achieved by Albert the Great (d. 1280) and Thomas Aquinas (d. 1274). ${ }^{3}$ The latter set the standards both regarding perspective as well as the approach to be taken in the ongoing debate.

The issue of the relation of faith and reason has been one of the most debated in the history of Western thought. Even in our times there has been a renewed interest in this debate which has engaged the then Cardinal Joseph Ratzinger (today Pope Emeritus Benedict XVI) and the German philosopher Jürgen Haber-

\footnotetext{
${ }^{1}$ Joseph Ellul, dominikanin, profesor Wydziału Teologicznego Uniwersytetu na Malcie oraz Papieskiego Uniwersytetu św. Tomasza z Akwinu „Angelicum” w Rzymie, autor wielu prac z zakresu islamologii oraz dialogu z Islamem rozpatrywanego w kontekście teologii św. Tomasza z Akwinu.

${ }^{2}$ John Paul II, Fides et Ratio, Vatican City: Libreria Editrice Vaticana, 1998, n. 42.

${ }^{3}$ See P. Zerafa, O.P., "Alterità Mitologika u Alterità Filosofika," in KNISJA 2000, n. 21(1992), pp. $14-15$.
} 
mas. ${ }^{4}$ In Islam, however, the debate that has taken place down through the centuries was markedly different. Whereas in the West the fundamental issue centred upon the question as to whether or not the conclusions of reason were contrary to the truths of the Christian faith, the problem in Islam concerned the very existence of philosophy within its domains.

\section{Islamic philosophy and Muslim orthodoxy}

Islam's claim to be a revealed religion greatly influenced the reception of the classical Hellenic tradition within its societies. With the passing centuries, Islam saw increasing concern among its religious scholars ('ulama') about the legitimacy of what were referred to as the "foreign" or "rational" sciences (as opposed to the "traditional" or "Islamic" sciences). In fact, the Arabic term applied to philosophy was falsafa, a corruption of the Greek philosophia. This was in order to highlight the alien roots of this science, thereby emphasizing its supposedly non-Islamic and, perhaps in the minds of some, anti-Islamic, nature. There is no question that scholars who promoted Platonic or Aristotelian metaphysics were frequently called on to defend themselves against a theological backlash from the upholders of Islamic orthodoxy. Already during the first centuries of Islam many religious scholars questioned the need for the pursuit of philosophy when, in their view, the Qur'ân contained all that was necessary for one to achieve happiness in this world and in the next.

For their part, philosophers considered religion as the sole cohesive force of society; without religion society would disintegrate. It could not, therefore, be brushed aside, nor could it be dismissed as superstitious nonsense. It was a factor that had to be taken into account and to be reckoned with. As we shall see throughout this article, Islam as a religion has consistently remained the tribunal before which pursuit of the sciences was sometimes justified - when justification was called for, something that became an increasingly frequent occurrence.

At times philosophers were obliged to camouflage their ideas by way of dissimulation (taqiyya); an attitude of self-preservation originally adopted by the $\breve{S} \overline{1}$ 'a in the face of persecution periodically unleashed upon them by Sunnī authorities. For this reason Šì'a scholars, especially commentators of the Qur'ân (mufassirūn) applied both an exoteric (zāhir) and an esoteric (bātinin) interpretation of the sacred text. In the words of Joel Kraemer, philosophers, following the example of the Šî'a "often conformed in their writing to accepted views, while confidentially communicating outrageous doctrines to their coteries or writing esoterically". 5

${ }^{4}$ See J. Habermas, J. Ratzinger, The Dialectics of Secularization: On Reason and Religion, San Francisco, Ignatius Press 2007.

${ }^{5}$ J.L. Kraemer, Humanism in the Renaissance of Islam, Leiden: E.J. Brill, 1992, p. 14. 


\section{The Islamic peripatetic schools ${ }^{6}$}

The two major Islamic philosophers who indirectly broached the issue of religious discourse and philosophy were Abū Nașr al-Fārābī (d. c. 950) and Abū 'Alī b. Sīnā (d. 1037). For the former, philosophy, and particularly metaphysics, is absolutely and universally true, but accessible only to a small intellectual élite. The masses therefore need something they could relate to, that is, religion, which must be adapted to particular cultures.

According to al-Fārābī, "philosophy gives an account of the ultimate principles... as they are perceived by the intellect," whereas "religion sets forth their images by means of similitudes of them taken from corporeal principles and imitates them by their likenesses among political offices". ${ }^{7}$ Such a doctrine flies in the face of Muslim orthodox teaching on the role and the mission of Muhammad.

Ibn Sīnā draws the same distinction between philosophy and religion by presenting prophecy as the culmination of intellectual development, a grasp of the intelligibles. The prophet must lay down laws about men's affairs by the permission of God... [But] he ought not to involve them with anything [doctrinal] pertaining to the knowledge of God, exalted be $\mathrm{He}$, beyond the knowledge that $\mathrm{He}$ is One, the Truth, and has nothing similar to Him. To go beyond this and obligate them to believe in His existence as being not referred to in place, as being not subject to verbal classifications, as being neither inside nor outside the world, nor anything of this kind [is to ask too much]. ${ }^{8}$

Both al-Farābī's and Ibn Sīnā's philosophic argumentation were bold attempts to fuse Aristotelian metaphysics and the Neoplatonic notion of celestial hierarchies with the creator God of the Qur'ân. But it also brought about an angry reaction from the Mutakallimūn (theologians), ${ }^{9}$ which led one of Islam's most

\footnotetext{
${ }^{6}$ By peripatetic schools I intend those schools of thought in Islam that embraced Platonic or Aristotelian thought, or an interpretation of both in a Neoplatonic mode.

${ }^{7}$ See al-Fārābī, The Attainment of Happiness, in Alfarabi: Philosophy of Plato and Aristotle, translated with an introduction by Muhsin Mahdi (revised edition), Ithaca, New York: Cornell University Press, 2001, n. 55, p. 45.

${ }^{8}$ See Avicenna: The Metaphysics of "The Healing", translated, introduced, and annotated by M.E. Marmura, Provo, Utah: Brigham Young University Press, 2005, pp. 365-366, nn. 4.5.

${ }^{9}$ The Arabic term denoting 'theology' is 'ilm al-kalām, meaning literally 'the science of the words", that is to say, the words of the Qur'ân. Thus, the Arabic term expressing the equivalent of "theologian" is mutakallim (pl. mutakallimūn), meaning "a scholar of the words". Thomas Aquinas (as well as Bonaventure) applies a specific Latin term when referring to Muslim theologians, namely Loquentes or Loquentes in lege Maurorum (see, for instance Summa contra Gentiles Book III, Chapter 97:15), which expresses precisely their role in the Muslim community. According to the renowned scholar Louis Gardet, Aquinas acquired his knowledge of the doctrines of the Mutakallimūn from Maimonides. See Gardet, "Saint Thomas et ses prédecesseurs arabes," in A. Maurer (ed.), St. Thomas Aquinas 1274-1974, Commemorative studies, Toronto: Pontifical Institute of Mediaeval Studies, 1974, I, pp. 419-448. This opinion is reinforced by the above-mentioned text from the Summa contra Gentiles.
} 
illustrious scholars, Abū Ḥāmid al-Ġazālī (d. 1111), to articulate a robust defence of Islamic orthodoxy.

\section{Al-Ġazālī and the reaction of orthodoxy}

Al-Ġazālì's critique of their ideas in his refutation The Incoherence of the Philosophers (Tahâfut al-Falāsifa) is considered to have sounded the death-knell of philosophical speculation in the Eastern Islamic lands. Others suggest that his life's work brought about the subsequent absorption of Islamic philosophy into Islamic mysticism, despite the later efforts of Ibn Rušd (d. 1198) to revive it. ${ }^{10}$ But, far from being a reactionary theologian, al-Ġazālī (d. 1111) warns against the improper use of apologetics or rushing into illogical statements. In the preface to this work he gives a timely warning to those who seek to undertake such a method of procedure:

The harm inflicted on religion by those who defend it in a way not proper to it is greater than [the harm caused by] those who attack it in a way proper to it. As it has been said: "A rational foe is better than an ignorant friend."

He was aware, as we see, that theology was in a weak position because of its inability to answer philosophical criticisms. The above quotation is a clear witness to his fellow theologians' insecurity when faced with profound philosophical questions that go right to the heart of the key beliefs of Islam. They merely dismissed such questions as foreign and dangerous. Al-Ġazālī is quick to point out that, in order to uphold the faith, it is not necessary to dispute against philosophical doctrines that do not clash with religious principle.

The main thrust of his argument against the philosophers, and particularly al-Fārābī and Ibn Sīnā, is that they had abandoned the teachings of the Qur'ân through their application of faulty metaphysical reasoning. ${ }^{12} \mathrm{He}$ considers both as "the most reliable transmitters and verifiers among the philosophers of Islam"13 of the words of Aristotle. For this reason they are singled out as the principal object of his refutation:

${ }^{10}$ See O. Leaman, art. IBN RUSHD, ABU 'L-WALID MUHAMMAD in Edward Craig (General Editor), Encyclopedia of Philosophy, London: Routledge, 1998, pp. 638f.

${ }^{11} \mathrm{Al}-\mathrm{G}$ Gazālī, The Incoherence of the Philosophers, A parallel English-Arabic text translated, introduced, and annotated by M.E. Marmura, Provo, Utah: Brigham Young University Press, 2002, [A second] introduction n. 16, p. 6. All the texts from the Tahâfut quoted in the article will be taken from this translation.

${ }^{12}$ See al-Ġazālì, op. cit., [A first introduction], n. 10, p. 4.

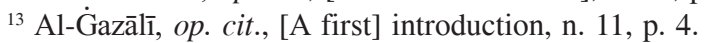


Let it be known that [our] objective is to alert those who think well of the philosophers and believe that their ways are free from contradiction by showing the [various] aspects of their incoherence. ${ }^{14}$

He formulates no less than twenty refutations of their ideas. While condemning their metaphysical arguments, al-Ġazāli approves their emphasis on the necessity of the study of logic: "When they say that the logical sciences must be mastered, this is true. But logic is not confined to them." 15 In making this statement he rightly points out that logic is not the sole preserve of philosophers, but it is also a science that is applied by theologians. He himself had defended the study of logic and claimed in his later intellectual autobiography Al-Munqid min al-Daläl that the logic of the falāsifa (philosophers) was superior to the reasoning of the religious scholars:

Logic is concerned solely with the concept, which is a question of definition, and with judging the truth of something, which is a question of proof. There is nothing in that which should be rejected. Scholastic and speculative scholars already have made use of it...

What connection is there between such logic and religious questions, which would require one to reject or condemn it? If you condemned it you would gain a poor reputation among the logicians, first of all for your own poor mind, but above all for the religion which you claim to be founded apparently on this denial. ${ }^{16}$

\section{Ibn Rušd's defence of philosophy}

Ibn Rušd (in Latin, Averroes) defended the status of the philosophers as well as the study of philosophy in three works, namely, the treatise Kitāb Fașl al-Maqāl wa Takrīr mä bayn al-šarī'a wa 'l-ḥikma min al-ittișāl (The Decisive Treatise Determining the Connection between the Law and Wisdom), the Kašf 'an manāhiğ al-adilla fi 'aqā'id al-milla (Uncovering the Methods of Proofs with Respect to the Beliefs of the Religious Community), and his monumental work Tahâfut al-Tahăfut (The Incoherence of the "Incoherence"). As Oliver Leaman judiciously affirms in his overall consideration of his writings, "Averroes' style is on the whole sober, careful, and considered. He makes his points fairly repetitively in many of his works in an attempt at expressing clearly what he is trying to say." 17

${ }^{14}$ Al-Ġazālī, op. cit., [A third] introduction, n. 22, p. 7.

${ }^{15}$ Al-Ġazālī, op. cit., [A fourth] introduction, n. 25, p. 9.

${ }^{16}$ Al-Ġazālī, Deliverance from Error and Mystical Union with the Almighty: Al-Munqidh min al-Ḍalāl, English translation with introduction by Muhammad Abūlayah, and Critical Arabic text established with Nurshīf Abdul-Rahīm Rif'at, Introduction and notes by G.F. McLean, Washington, D.C.: The Council for Research in Values and Philosophy, 2001.

${ }^{17}$ O. Leaman, Averroes and his philosophy, Richmond, Surrey: Curzon Press, 1998, p. 8. 
Besides providing a lengthy and detailed refutation of al-Ġazālī's arguments in his Tahăfut al-Tahăfut (The Incoherence of the "Incoherence"), Ibn Rušd offers in his Kitāb Fașl al-Maqāl a common defence of logic and philosophy, this time, however, one that is couched in terms of Islamic jurisprudence (fiqh). Indeed, this work is nothing else but a fatwa, a decision handed by a judge concerning a point of law upon which there appears to be a dispute or some sort of doubt. Besides his immense contribution as a philosopher, Ibn Rušd was also a $q \bar{a} d \bar{l}$ (judge) in the city of Cordoba could claim a pedigree in this profession since both his father and grandfather before him occupied the same position.

He also defends al-Fārābī and Ibn Sīnā against the charges of unbelief ( $k u f r$ ) brought against them by al-Ġazāli on three key issues namely, "the argument about the eternity of the world, that the Exalted does not know particulars - may He be exalted above that - and the interpretation of what is set forth about the resurrection of bodies and the way things are in the next life" ${ }^{18}$ He astutely begins with logic, and carries the justification of the study of this subject still further by arguing for its usefulness as an instrument for philosophy.

Throughout this relatively short treatise he frequently mentions al-Ġazālī, which implies that the latter's work Tahăfut al-Falāsifa had established itself as an apologetical text and made inroads even in Muslim Spain. The environment within which Ibn Rušd lived and worked was one fraught with tensions on both the political as well as the intellectual levels. Concerning the former, it must be noted that the military campaigns of the northern Christian kingdoms of Aragon and Navarre against Muslim Spain were putting the Muslim caliphate of the Almohads under constant pressure. What was required at this point was that society close ranks and avoid debate which could lead to dissent and the disintegration of the social order. On the intellectual level religious authorities were becoming increasingly wary of philosophical discourse, and their interpretation of al-Ġazālī's works did little to lighten the atmosphere of mistrust that pervaded intellectual encounters.

Ibn Rušd begins his treatise by posing the status quaestionis:

The goal of this statement is for us to investigate, from the perspective of Law-based reflection, whether reflection upon philosophy and the sciences of logic is permitted,

\footnotetext{
${ }^{18}$ Averroës, The Decisive Treatise determining the Connection between the Law and Wisdom \& Epistle Dedicatory, Translation, with introduction and notes by Ch.E. Butterworth, Provo, Utah: Brigham Young University Press, 2008, n. 16, p. 12. All the texts from the Kitāb Faṣl al-Maqāl quoted in the article will be taken from this translation. These charges are summarized by al-Ġazāli towards the end of the Tahăfut al-Falāsifa (see al-Ġazālī, op. cit., [Twentieth] Discussion, nn. 40-43, pp. 220-221) and again referred to by Ibn Rušd at the end of his Tahăfut al-Tahăfut (see Ibn Rušd, Tahạfut al-Tahăfut, 'About the Natural Sciences: The Fourth Discussion').
} 
prohibited, or commanded - and this as a recommendation or as an obligation - by the Law. ${ }^{19}$

He describes the study of philosophy as "nothing more than reflection upon existing things and consideration of them insofar as they are an indication of the Artisan," ${ }^{20}$ that is, God, as the Creator. Falsafa thus becomes natural theology, aiming to prove the existence of the creator and to provide a better understanding of God "through cognizance" (márifa). Later on in the text Ibn Rušd would apply this term when he addresses both the human cognizance of God (mairifa) and God's knowledge ('ilm) of the particulars.

In this way Ibn Rušd seeks to counter al-Ġazālī's charge that the falāsifa do not really prove that the world has an Artisan. In his Tahäfut al-Ġazālī had reiterated that "Real action is only through will" whereas "If God, according to [the philosophers], has neither will nor choice, he would be neither an agent nor a maker except in a metaphorical [sense]." 21

A crucial decision taken by Ibn Rušd's in order to set philosophy within the parameters of Islamic orthodoxy was to change certain key terms. In the title of his Fașl al-Maqāl, he does not apply the term falsafa but instead he opts in favour of the term hikma. In the text of the same work he does not refer to Islam as din (the common phrase applied in order to denote 'religion'), but instead applies the term šari ${ }^{\prime} a$ which, in the above quotation is translated as Law-based reflection. ${ }^{22}$ Concerning the first choice, it should be noted that one of the most beautiful names of God mentioned in the Qur'ân is al-Hakim, the All-Wise; whereas, concerning the second, he intends to place the study of philosophy before the ultimate tribunal of God's classification of human acts. He is careful to apply the terms current in classical Islamic jurisprudence regarding the five classifications under which human acts fall, namely: wāğib (obligatory), mandūb (recommended), mubāh (permitted), makrūh (reprehensible), and maȟzūr (forbidden). In the text quoted above Ibn Rušd opts in favour of grouping wāğib and mandūb under the more comprehensive class of ma'mūr (commanded), while leaving out altogether the class of makrūh..$^{23}$

He begins the third section of the treatise by claiming that for every Muslim there is a way to truth that suits his nature. He elaborates his assertion in the following manner:

\footnotetext{
${ }^{19}$ Averroës, The Decisive Treatise determining the Connection between the Law and Wisdom \& Epistle Dedicatory, [I. Introduction], n. 1, p. 1

${ }^{20}$ Averroës, op. cit., [II. That philosophy and logic are obligatory], n. 2, p. 1.

${ }^{21}$ Al-Ġazâlî, The Incoherence of the Philosophers, Discussion 3 (13), p. 59.

${ }^{22}$ In a note to the translation Butterworth states that the term šaría (or its equivalent $\check{s} a r^{\circ}$ ) "are used only to refer to the revealed law of Islam." See Averroës, op. cit., p. 51, n. 1.

${ }^{23}$ See ibid.
} 
Thus, some assent by means of demonstration; some assent by means of dialectical statements in the same way the one adhering to demonstration assents by means of demonstration, there being nothing greater in their natures; and some assent by means of rhetorical statements, just as the one adhering to demonstration assents by means of demonstrative statements. ${ }^{24}$

He bolsters his argument by referring the reader to Q. 16:125, which states: "Call to the path of your Lord by wisdom, fine preaching, and arguing with them by means of what is finest." ${ }^{25}$ He takes the term "wisdom" ( cal with "demonstration" (burhān), "fine preaching" (al-maw iza al-asana) as identical with "rhetorical statements" (al-aqūwīl al-hițābiyya), and "arguing with

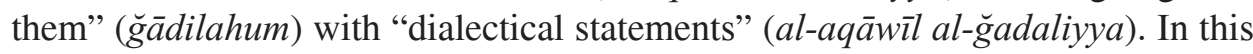
manner he is eventually able to present philosophy as one of three ways towards fulfilling the Qur'ânic injunction, one which is obligatory albeit for a very restricted circle of individuals:

For people are of three sorts with respect to the Law.

One sort is in no way adept to interpretation. These are the rhetorical people, who are the overwhelming multitude. That is because no person of unimpaired intellect is exempted from this kind of assent.

Another sort is those adept in dialectical interpretation. These are those who are dialectical by nature alone, or by nature and by habit.

Another sort is those adept in certain interpretation. These are those who are demonstrative by nature and art - I mean, the art of wisdom. This interpretation ought not to be declared to those adept in dialectic, not to mention the multitude. ${ }^{26}$

Thus, by setting aside some of the distinctions between the language of the Qur'ân and technical Greek philosophical terms and concepts, Ibn Rušd is able to claim at the end of the Treatise that "wisdom (hikma but now rendered synonymous with falsafa) is the companion of the Law and its milk-sister (șâhibat alšarī $a$ wa ' $l-u \underline{h t} a l-r a d \bar{l}^{\prime} a$ ). These two are companions by nature and lovers by essence and instinct." 27

${ }^{24}$ Averroës, op. cit., [III. That demonstration accords with the Law], n. 11, p. 8.

${ }^{25}$ In this particular paragraph I have opted for Butterworth's translation in the text itself.

${ }^{26}$ Averroës, op. cit., [V. On what is intended by the Law and its methods], n. 44, p. 26. This distinction is already present in Plato's Republic, VI wherein Socrates states that "those who are able to grasp what is always the same in all respects are philosophers, while those who are unable to do so and who wander among the many things that vary in every sort of way are not philosophers." Plato Republic VI:484b in Plato: Complete Works, Edited, with Introduction and Notes, by J.M. Cooper, Indianapolis/Cambridge, Massachusetts: Hackett Publishing Company, 1997, p. 1107. Al-Fārābī applied it to his political philosophy.

${ }^{27}$ Averroës, op. cit., [VII. Conclusion], n. 9, pp. 32-33. This statement clinches the argument that the treatise is indeed a fatwa. The term milk-sister $\left(a l-u \underline{h} t a l-r_{a d} \bar{\imath}^{\prime} a\right)$ is a legal term used in cases concerning the prohibition of a marriage on account of fosterage (breast-feeding). Al-Alami and Hinchcliffe have very aptly described this legal issue: 
Too many interpreters, unaware of such shifts in terminology and of cultural differences, have operated under the assumption that Ibn Rušd was particularly concerned with the relation between philosophy and religious faith that was similar to the one posed by the thirteenth century Scholastics in the wake of the Averroist movement in Paris. However, as stated above, Ibn Rušd does not in fact refer to religion but rather to $\check{s}^{\prime} \bar{r}^{-} a$. What was at stake was the legitimacy of the study of philosophy in Islam. As is evident from the above-quoted text, this relation he asserts between philosophy and Law is one of accord, but only for a selectfew.

Thus religion (here identified with Law) and philosophy are not incompatible. The Qur'ân enjoins its adherents to attend to rational arguments concerning how they are to behave and think. For those who cannot, however, there are other forms of presentation of the truth which are more within the reach of the multitude of people. Ibn Rušd expands his argument in his Taḥăfut al-Taḥâfut:

[T] he religions are, according to the philosophers, obligatory, since they lead towards wisdom in a way universal to all human beings, for philosophy only leads a certain number of intelligent people to the knowledge of happiness, and they therefore have to learn wisdom, whereas religions seek the instruction of the masses generally. ${ }^{28}$

He further develops his argument by stating that "a man of learning", that is to say, a philosopher, "is under obligation to choose the best religion of his period, even when they are all equally true for him, and he must believe that the best will be abrogated by the introduction of a still better". ${ }^{29}$ From this premise, he concludes:

Therefore the learned who were instructing the people in Alexandria became Muhammedans when Islam reached them, and the learned in the Roman Empire became

Foster relationship also creates a bar to marriage in Islamic jurisprudence. The Qur'ân itself merely prohibits the marriage of a man with his foster mother and her daughters. The jurists, however, extended the bar of fosterage and virtually equated it with that of blood relationship. Thus not only may a man not marry the woman who suckled him, or her daughter, he may not marry the mother or grandmother of his wet-nurse, his daughter by fosterage, i.e. his wife's foster child and her descendants, or his foster sisters and her descendants, the paternal and maternal aunts of his foster-mother. The jurists also extended the bar of fosterage and virtually equated it with that of affinity. Thus a man is forbidden to marry the wives of his son by fosterage, i.e., the wives of those his wife has suckled and the wives of his foster-father, i.e., the husband of his wet-nurse, and their ascendants and descendants. He may not marry his wife's foster mother or her ascendants and descendants. A marriage is even prohibited between two persons who had different wet-nurses, if each of these women was the wife of the same man.

See Dawoud Sudqi El Alami and Doreen Hinchcliffe, Islamic Marriage and Divorce Laws of the Arab World, London-The Hague-Boston: Kluwer Law International, 1996, p. 13.

${ }^{28}$ Averroes' Tahafut al-Tahafut, translated by Simon van den Bergh, Cambridge, UK: Gibb Memorial Trust, 1954, n. 582, p. 360.

${ }^{29}$ Op. cit., n. 583. 
Christians when the religion of Jesus was introduced there. And nobody doubts that among the Israelites there were many learned men, and this is apparent from the books which are found amongst the Israelites and which are attributed to Solomon. ${ }^{30}$

What Ibn Rušd is stating here is that reason is the path that leads to the truth of the prophetic tradition, which explains successive conversions of the philosophers to the revealed Laws of their times. The learned, of their own nature tend to opt for the best religion of their times. ${ }^{31}$ He further states that "every religion exists through inspiration and is blended with reason". ${ }^{32}$

Taking his cue from the teachings of al-Fārābī, Ibn Rušd affirms that the role of religion is that of instructing people in social mores and good conduct both of which lead to happiness. But those belonging to the demonstrative class (i.e., the philosophers) are enjoined to address religious propositions in a critical manner. ${ }^{33}$ This might appear to be a rather condescending way to describe the faith of the ordinary believer but, as he suggests in Faṣl al-Maqāl, if one considers examples from medicine its acceptability will become evident:

Here is a likeness of these people's intention as contrasted to the intention of the Lawgiver: someone is intent upon [going to] a skilled physician who is intent upon preserving the health of all the people and removing sicknesses from them by setting down for them statements to which there is common assent about the obligation of practicing the things that preserve their health and remove their sicknesses, as well as of avoiding the contrary things. He is not able to make them all become physicians, because the physician is the one who knows by demonstrative methods the things that preserve health and remove sickness...

Now this illustration is certain ... That is because the link between the physician and the health of bodies is [the same as] the link between the Lawgiver and the health of souls - I mean, the physician is the one who seeks to preserve the health of bodies when it exists and to bring it back when it has disappeared, while the Lawgiver is the one who aspires to this with respect to the health of souls. ${ }^{34}$

${ }^{30}$ Ibid.

${ }^{31}$ Alain de Libera in Averroès: L'islam et la raison, traduction par Marc Geoffroy, presentation par A. de Libera, Paris: GF Flammarion, 2000, p. 35.

${ }^{32}$ Averroes' Tahafut al-Tahafut, n. 584.

${ }^{33}$ Richard C. Taylor 'Averroes: religious dialectic and Aristotelian philosophical thought', Peter Adamson \& Richard C. Taylor, The Cambridge Companion to Arabic Philosophy, Cambridge, UK: Cambridge University Press, 2005, p. 187.

${ }^{34}$ Averroës, The Decisive Treatise determining the Connection between the Law and Wisdom \& Epistle Dedicatory, [V. On what is intended by the Law and its methods], nn. 48.50, pp. 27-29. This parallel between the Lawgiver and the physician is not a novelty in philosophy. Already al-Fārābī in his treatise Al-Tanbīh 'alā sabīl al-sa'äda (Directing Attention to the Way to Happiness) resorts to the same example in order to describe the role of the ruler as moral teacher within a virtuous city. He juxtaposes role of the physician to that of the statesman or ruler insofar as the first cures bodies and the second cures souls. This comparison leads al-Farābī to move from the individual level to the social. See al-Fārābī, The Attaiment of Happiness, in Alfarabi: Philosophy of Plato and Aristotle, n. 62. 
Different people possess different attitudes toward medicine, some based upon real understanding and some based upon a superficial acquaintance, and yet these differences do not pose any obstacle to the ability of everyone in the community to live in an organized and healthy society. Throughout his Faṣl al-Maqāl, Ibn Rušd attempts to highlight the fact that there are various ways of arriving at knowledge of something, some of which are more certain than others, but all of which are acceptable. We know religious truths in different ways, but we really do know exactly the same thing. Following through his argument, Ibn Rušd affirms the existence of methods of interpretation of the Qur'ân which he describes as "the shared methods for teaching the majority of the people and [the method for teaching] the select." ${ }^{35}$ There are also three types of texts that lend themselves to interpretation: those requiring a literal interpretation, those requiring an allegorical one, and those concerning which disputes have arisen among scholars.

He ultimately claims that the philosopher is the best interpreter of the Qur'ân given that he is well trained in logic. ${ }^{36} \mathrm{~A}$ key term that Islam usually applies within a juridical-theological framework, but which Ibn Rušd applies to language, is $i \breve{g} m \bar{a}^{r}$ (consensus). This is connected with the interpretation of the Qur'ân, especially with those verses related to the above-mentioned issues on which al-Giazāli had accused the philosophers of unbelief:

Indeed, we say that whenever the apparent sense of a pronouncement about something in the Law $^{37}$ differs from what demonstration leads to, if the Law is considered and all its parts scrutinized, there will invariably be found in the utterances of the law something whose apparent sense bears witness, to that interpretation.

Because of this idea, Muslims have formed a consensus that it is not obligatory for all utterances of the Law to be taken in their apparent sense, nor for all of them to be drawn out from their apparent sense by means of interpretation, though they disagree about which ones are to be interpreted and which not interpreted. ${ }^{38}$

At this point Ibn Rušd mentions the divergent schools of the Ašariyya ${ }^{39}$ and of the Hanbaliyya. ${ }^{40}$ Consequently, if an "exhaustive" consensus exists among all

${ }^{35}$ Averroës, op. cit., [VI. On the emergence of factions within Islam], n. 55, p. 31.

${ }^{36}$ This opinion had already been voiced by al-Fārābī who believed that logicians are better interpreters of the Qur'ân than grammarians. See, for instance, his treatise Al-Alfāza al-Mustámalah.

${ }^{37}$ Here the term 'Law' refers to the Qur'ân.

${ }^{38}$ Averroës, op. cit., n. 14, pp. 9-10.

${ }^{39}$ The Aš ariyya School, founded in Bașra by Abū 'l-Ḥasan 'Alī b. Ismāê̄l al-Aš arī (d. c. 935), advocated the doctrine of divine attributes as corresponding to realities in God and not merely with his essence. They also upheld the doctrine of divine omnipotence to the extent that, for them, even human action is created by God.

${ }^{40}$ The Hanbaliyya School, founded in Baghdad by Ahmad b. Hanbal (d. 855). It gives priority to the Qur'ân to the text of the Qur'ân and the hadīt (Sayings of the Prophet) and adopts a literalist approach to the sacred text. It adopts a rigorist stand as regards morality and ethics. 
three classes (demonstrative, dialectical, rhetorical) concerning the clarity of certain verses, then there is no need to seek other forms of interpretation except the literal one. Where a certain ambiguity appears with regard to other passages of the Qur'ân, then these are to be interpreted allegorically. In this way, Ibn Rušd is able to conclude eventually that, where there appears to be a clash between demonstrative reasoning and the verses of the Qur'ân, which are commonly interpreted in a literal sense, then these same verses require an allegorical interpretation:

The reason an apparent and an inner sense are set down in the Law is the difference in people's innate dispositions and the variance in their innate capacities for assent. The reason contradictory apparent senses are set down in it is to alert "those well grounded in science" to the interpretation that reconciles them. This idea is pointed to in His statement (may He be exalted), "He it is who has sent down to you the Book; in it there are fixed verses..." on to His statement, "and those well grounded in science" $(\mathrm{Q} .3: 7)^{41}$

Here Ibn Rušd is referring to the distinction between so-called "clear verses" (âyāt muhkamāt) and the "ambiguous verses" (âyāt mutašāaihāt) of the Qur'ân. At this point the question arises as to who should be the one tasked with either or both types of interpretation. The distinguished Muslim exegete al-Tabarī (d. 923) states that the "clear verses" are accessible to Muslim scholars ('ulamä'), whereas the comprehension of the "ambiguous verses" is the sole prerogative of God..$^{42}$ What Ibn Rušd is claiming here, however, is that the "clear verses" are amenable to only one interpretation, which applies to both the learned and the masses. By contrast the "ambiguous verses" can be interpreted only by the learned (in his case, the philosophers), who can read into them and arrive at an allegorical interpretation of that particular verse or verses where an apparent conflict exists between their literal interpretation and the teachings of the philosophers, particularly those of Aristotle. Thus, when Ibn Rušd attempts to reconcile apparently contradictory views his approach is to argue that all these views are acceptable as different aspects of one and the same reality. Throughout his works he strives to demonstrate that one thing could be described in a variety of manners.

\section{The decline of Islamic Peripatetic philosophy}

In describing the sad demise of peripatetic philosophy in Islam following the downfall of Ibn Rušd, Oliver Leaman states that:

\footnotetext{
${ }^{41}$ Averroës, op. cit., n. 14, p. 10.

${ }^{42}$ See Țabarī, Ğămi' al-bayān 'an tảwōl ây al-Qur'ân, Maḥmūd Muhammad Šakīr and Aḥmad Muhammad Šakīr (eds), Cairo: Dār al-Ma ārif, 1374/1954-, VI. 179-180.
} 
Towards the end of his life Averroes suffered persecution from the Almohad authorities, and although he was fairly swiftly rehabilitated, philosophy itself fell into something of a disgrace within the Muslim community. In the eastern territories of Islam there were flashes of philosophical revival within the tradition of falsafa, and the name of Mulla Sadra (c. 1571-1640) is well worth mentioning in this context, but in al-Andalus and the western region very little activity of philosophical note was built upon the foundations laid by Averroes. ${ }^{43}$

It is indeed one of those seeming contradictions in history that the true heir of Ibn Rušd's thought was not the Muslim world but Western Scholasticism. His ideas, some of which were hotly contested during the thirteenth century were eventually addressed and assimilated within the fabric of Mediaeval Christian thought. Thus, it is no small wonder that, whereas in his monumental Divine Comedy, Dante Alighieri placed Muhammad and 'Alī in the Eighth Circle of Hell among the "sowers of scandal and schism", ${ }^{44}$ he assigned Ibn Rušd ("Averroës, of the great Commentary") ${ }^{45}$ to the First Circle of Hell (or Limbo), ${ }^{46}$ in the company of Homer, the Pre-Socratics, Socrates, Plato, Euclid, Ptolemy, Hippocrates, Galen, Ibn Sīnā (Avicenna) and Salạ̣ al-Dīn (Saladin).

\section{The debate in Western Scholasticism}

The study of philosophy in Western Christendom and in particular during the High Scholastic period $\left(12^{\text {th }}-13^{\text {th }}\right.$ centuries $)$ had its own travails, albeit of a different kind. In effect philosophy was present within the fabric of the Christian tradition already in the preaching of Paul. The Apostle of the Gentiles was not only instructed in the niceties of the Jewish faith but also in some areas of Greek thought, especially the principles of rhetoric. Later on, St Justin Martyr (d. c. 165) was reputed to have been the first Christian philosopher among the Fathers of the Church. In the Eastern Christian tradition one finds Church Fathers of outstanding repute such as St Basil of Caesarea (d. 379) and his companion St Gregory of Nazianzus (d. 390), both of whom studied philosophy at the Academy of Athens (which was a pagan institution). In the Western tradition no less a figure than St Augustine (d. 430), arguably the greatest Father of the West, not only studied but also taught philosophy both at Carthage and in Milan. In later centuries one could boast of great philosophers such as the Irish theologian and Neoplatonist John Scotus Eriugena (d. c. 877).

${ }^{43}$ O. Leaman, Averroes and his Philosophy, p. 163.

${ }^{44}$ See Dante Alighieri, The Divine Comedy, Inferno: Canto XXVIII vv. 28-42.

${ }^{45}$ Dante Alighieri, The Divine Comedy, Inferno: Canto IV v. 144.

${ }^{46}$ According to Dante this place is inhabited by admirable men and women who lived before the advent of Christianity or who did not receive baptism. 
The teachings of Augustine, especially those on divine illumination were later applied to the thought of Ibn Sīnā whose writings witnessing his engagement with and his debt to Neoplatonic thought were introduced to Western Scholastic circles in the early thirteenth century especially through the works of William of Auvergne (d. 1249). It is no small wonder that Étienne Gilson coined the term augustinisme avicennisant. ${ }^{47}$

To state that the appearance of Islamic thought was like a beacon that shone upon an otherwise intellectually depleted, backward and superstitious Western Christendom is unfortunately a very common and simplistic opinion. It is true that Christian scholars such as Gerbert d'Aurillac (later Pope Sylvester II, d. 1003) and Adelard of Bath (d. 1152) travelled to Muslim lands in order to seek knowledge and to broaden their intellectual horizons. They even brought back to Christian Europe scientific works and instruments that greatly revolutionized Western science. It is also true that the introduction of philosophical works by Islamic scholars did cause intellectual upheaval in the great universities of Europe, especially in Paris. But this was only possible precisely because Western Christian scholars were fully capable of understanding such writings and the potential consequences of their adoption without the necessary dynamic engagement through dialogue and critique. The problem lay not with Greek or with Islamic thought per se, but with the infiltration of Aristotelian works through the commentaries of Ibn Rušd.

Throughout the thirteenth century the University of Paris was, in a phrase coined by Pope Gregory IX (one of its ex-alumni), the oven where the intellectual bread of the Latin world was baked. It was the domain par excellence of high culture. Albert the Great called it "the city of philosophers." But some time before the year 1230 a significant change took place within this academic institution. Two centuries earlier the Christian kingdoms of northern Spain had launched a series of military campaigns, known as the Reconquista in order to loosen the Muslims' grip on Spain. The first result was the capture of the city of Toledo in 1085. This military thrust facilitated freedom of movement for Christians and brought about a missionary thrust that was essentially doctrinal in nature. Thus began the dialogue of apologetics spearheaded by the monks of Cluny under the leadership of Peter the Venerable (d. 1156). Meanwhile, Arab-Islamic culture was also the strongest exponent of ancient Greek science and philosophy; to the mind of the mediaeval Latin West it represented both a threat and an unavoidable attraction. It is, therefore, understandable that Arab-Islamic writings that drew upon Greek inspiration were being translated within Latin Christendom through the initial efforts of Dominicus Gundissalinus (d. c. 1181) and Gerard of Cremona (d. 1187).

${ }^{47}$ See É. Gilson, Les sources gréco-arabes de l'augustinisme avicennisant, Paris: Librairie Philosophique J. Vrin, 1986, p. 101f. 
It was precisely this process of translation that two centuries later brought about a veritable crisis of high culture in Paris. The introduction of Aristotle as interpreted by Ibn Rušd around 1230 opened up for Christians a scientific view of the universe that was in some instances far removed from the Bible's religious imagery. The enthusiastic response and, at times, uncritical acceptance on the part of many Parisian scholars of the Aristotelian corpus by way of Islam was viewed by others with a sense of alarm; for these, pagan thought had infiltrated the very fabric of Christianity through the writings of an infidel, namely Ibn Rušd. Paris had become the city of the Gentiles. ${ }^{48}$ Such fear was reinforced in the wake of the controversies that erupted as a result of the teachings of Amaury of Bène (d. c. 1207) and David of Dinant (d. c. 1217), both of whom were condemned as pantheists, as well as Siger of Brabant (d. c. 1284), who was considered the main proponent of the so-called Averroist School at the University of Paris ${ }^{49}$ It is within this framework that one must set the life and works of Thomas Aquinas as well as his unique contribution towards a better understanding of the role of faith and reason.

The Mediaeval thinker was a person who had a passion for knowledge; he was always prepared to initiate an exchange of ideas in order to arrive at the truth. He was confident of human reason and rational discourse which, enlightened by faith, would lead to divine truth. Saint Thomas Aquinas was one of the major proponents of such discourse, and it is precisely within this context that we discover in him a man of dialogue, not only with the philosophical currents of his time, but also with the religious, including Islam. His careful reading of Aristotle as well as his response to the Stagirite's commentators in the Islamic world would occupy his entire career as a scholar.

\section{Thomas Aquinas on faith and reason}

In Fides et Ratio John Paul II reserves special praise for Aquinas "not only because of what he taught but also because of the dialogue which he undertook with the Arab and Jewish thought of his time." John Paul II sets this medieval scholar's contribution to the ongoing dialogue between faith and reason within the historical and cultural context of his time:

In an age when Christian thinkers were rediscovering the treasures of ancient philosophy, and more particularly of Aristotle, Thomas had the great merit of giving pride of place to the harmony which exists between faith and reason...

${ }^{48}$ It is interesting to note that, for this reason, the Summa contra Gentiles is considered by some modern authors as a work addressed to Masters of the Faculty of Arts at the University of Paris. See, for instance, See M.-D. Chenu, Aquinas and His Role in Theology, Collegeville, Minnesota: Michael Glazier, 2002, p. 66.

${ }^{49}$ See O. Leaman, Averroes and his philosophy, pp. 163-178. 
More radically, Thomas recognized that nature, philosophy's proper concern, could contribute to the understanding of divine Revelation. Faith has no fear of reason, but seeks it out and has trust in it..$^{50}$

One may wonder at the fact that Aquinas sought the assistance and was indeed influenced by philosophers who embraced non-Christian beliefs, more so when these happened to be Jewish and Muslim. As already stated above, Christendom had already been fighting the Crusades in the East for two centuries and the Spanish reconquista was steadily gaining ground in the West. As for the Jews, there was an almost universal impression that the old Mosaic covenant had been eclipsed by the new, although Christian scholars concerned about the textual accuracy of their Old Testament did turn to the Jewish scholars for the necessary elucidation, with some even learning a little Hebrew. The late twelfth and early thirteenth centuries saw a flourishing of Hebraic studies that remained unparalleled until the later Renaissance.

However the main concern of Aquinas was to learn from them in his search for the truth. In this respect he epitomized the medieval respect for learning, through his conviction that "any truth, no matter by whom it is said, is from the Holy Spirit". ${ }^{51}$ Such an innovative and courageous attitude was highlighted by his biographer and secretary William of Tocco when he wrote:

For he was making new divisions in his text, finding a new and clear manner of drawing conclusions, and adducing new reasons for his conclusions, such that no one who heard him teach new things, or define doubtful things by new arguments, could doubt that God had illuminated him..$^{52}$

For this reason John Paul II, does not fail to emphasize this contribution of Thomas which serves as a model as well as a condition for any dialogue that aims to be serious and fruitful:

${ }^{50}$ Fides et Ratio, n. 43.

${ }^{51}$ Summa Theologiae, Ia IIae, q. 109, art. 1.

${ }^{52}$ This text refers to chapter xiv of the Vita Sancti Thomae Aquinatis written by William of Tocco. The Latin original reads:

Erat enim novos in sua lectione movens articulos, novum modum et clarum determinandi inveniens, et novas adducens in determinationibus rationes: ut nemo, qui ipsum audisset nova docere, et novis rationibus dubia diffinire, dubitaret, quod eum Deus novi luminis radiis illustrasset.

Vita Sancti Thomae Aquinatis, auctore Guillelmo de Tocco, in Fontes Vitae S. Thomae Aquinatis (notis historicis et criticis illustrati), curis et labore D. Prümmer O.P., Fasciculus II, Tolosa s.d., p. 81.

The context of this quotation refers to the preparatory studies undertaken by Thomas in order to accede to the Baccalaureate. At one time he was hesitating whether to continue, considering himself unworthy of such an academic position. He was then persuaded to continue thanks to the intervention of St. Albert the Great. 
A quite special place in this long development belongs to Saint Thomas, not only because of what he taught but also because of the dialogue which he undertook with the Arab and Jewish thought of his time. In an age when Christian thinkers were rediscovering the treasures of ancient philosophy, and more particularly of Aristotle, Thomas had the great merit of giving pride of place to the harmony which exists between faith and reason. Both the light of reason and the light of faith come from God, he argued; hence there can be no contradiction between them. ${ }^{53}$

Thus, in the words of David Burrell, Aquinas "was more inclined to examine the arguments of thinkers than their faith, trusting in the image of the creator in us all to search out traces of the divine handiwork." 54

Thomas refers many times to the question of faith and reason directly or indirectly throughout his academic career. At the beginning he broaches the subject indirectly when discussing the issue within the context of the debate concerning the creation, in his In quattuor libros Sententiarum of Peter Lombard. Here he states unequivocally that the existence of the Creator and his uniqueness, together with his freedom to create and his creation of things ex nihilo and without intermediaries is philosophically both comprehensible and demonstrable. Only the question of creation ex tempore cannot be subject to demonstration by way of philosophy, although it is comprehensible. ${ }^{55}$ Aquinas would again take up this question near the end of his career in his work De aternitate mundi.

He later wrote specifically on the question of faith and reason and approached the subject from three perspectives, namely: on whether the conclusions derived from reason are opposed to the truth of the Christian faith; on the type of knowledge of God that can be attained by means of faith and of reason; and on whether matters of faith could be demonstrated by way of rational argumentation.

Aquinas discusses the first issue, namely whether the truth of reason is opposed to the truth of the Christian faith, especially in the Summa contra Gentiles. He gives seven reasons for why the truth of reason is not opposed to that of the Christian faith, the principal ones being the first two, namely:

[1] Although the truth of the Christian faith... surpasses the capacity of the reason, nevertheless that truth that the human reason is naturally endowed to know cannot be opposed to the truth of the Christian faith. For that with which the human reason is naturally endowed is clearly most true; so much so, that it is impossible for us to think of such truths as false. Nor is it permissible to believe as false that which we hold by faith, since this is confirmed in a way that is so clearly divine. Since, therefore, only

${ }^{53}$ Pope John Paul II, Fides et Ratio, n. 43.

${ }^{54}$ D.B. Burrell, C.S.C., "Aquinas and Islamic and Jewish Thinkers" in Norman Kretzmann and Eleonore Stump (eds.), the Cambridge Companion to Thomas Aquinas, Cambridge, UK: Cambridge University Press, 1993, p. 61.

${ }^{55}$ See Aquinas, In quattuor libros Sententiarum, Book II, Dist. 1, Q. 1, Art. 1-6. 
the false is opposed to the true, as is clearly evident from an examination of their definitions, it is impossible that the truth of faith should be opposed to those principles that the human reason knows naturally.

[2]... The knowledge of the principles that are known to us naturally has been implanted in us by God; for God is the Author of our nature. These principles, therefore, are also contained by the divine Wisdom. Hence, whatever is opposed to them is opposed to the divine Wisdom, and therefore, cannot come from God. That which we hold by faith as divinely revealed, therefore, cannot be contrary to our natural knowledge. ${ }^{56}$

The above passage reveals the focal point of his system, namely that the human mind was created in order to receive the truth. It is precisely for this reason that Aquinas had earlier discussed the way one would be able to argue with Jews, with non-Catholics, and with Muslims and pagans:

[3] ... against the Jews we are able to argue by means of the Old Testament, while against heretics we are able to argue by means of the New Testament. But the Muslims and the pagans accept neither the one nor the other. We must, therefore, have recourse to the natural reason, to which all men are forced to give their assent. However, it is true, in divine matters the natural reason has its failings. ${ }^{57}$

Regarding the second question, i.e., as to whether knowledge of God that can be attained by means of faith and reason Aquinas affirms in the Summa Theologiae that Christian theology is more valuable than the other sciences not because the latter do not possess validity, but because the truths of faith are beyond the grasp of human reason:

Among the theoretical sciences one is reckoned more important than another, first because of the certitude it brings, and next because of the worth of its subject. On both counts sacred doctrine surpasses the others. As to certitude, because theirs comes from the natural light of human reason which can make mistakes, whereas sacred doctrine's is held in the light of divine knowledge which cannot falter. As to worth of subject, because their business is only with things set under reason, whereas sacred science leads to heights the reason cannot climb.

Then among the practical sciences, that stands higher which has the further purpose... Now in so far as sacred doctrine is a practical science, its aim is eternal happiness, and this is the final end governing the ends of all the practical sciences. ${ }^{58}$

${ }^{56}$ Summa contra Gentiles, Book I, ch. 7, nn. 1.2. All texts from the Summa contra Gentiles are taken from Saint Thomas Aquinas, Summa contra Gentiles, Book One: God, translated with an Introduction and Notes by A.C. Pegis, F.R.S.C., Notre Dame, Indiana: University of Notre Dame Press, 1975.

${ }^{57}$ Summa contra Gentiles, Book I, ch. 2, n. 3.

${ }^{58}$ Summa Theologiae, Ia, q. 1, art. 5 corp. All quotations from the Summa are taken from the English translation published by Blackfriars in conjunction with Eyre \& Spottiswoode, London and McGraw-Hill, New York, 1964-1966. 
Concerning the third, that is to say, on whether matters of faith could be demonstrated by way of rational argumentation, Thomas admits in the Summa that Christian theology draws on philosophical teaching. However, he is quick to point out the reason and the manner in which this takes place:

Holy teaching can borrow from the other sciences, not from any need to beg from them, but for the greater clarification of the things it conveys. For it takes its principles directly from God through revelation, not from the other sciences. On that account it does not rely on them as though they were in control, for their role is ancillary and subsidiary... That it turns to them so is not from any lack or insufficiency within itself, but because our understanding is wanting, which is more readily guided into the world above reason, set forth in holy teaching, through the world of natural reason from which the other sciences take their course. ${ }^{59}$

He returns to the subject when he discusses the question of whether giving reasons for matters of faith lessens its merits. He replies that "human reasoning in matters of faith can stand in a twofold relationship to the believer's will." $\mathrm{He}$ replies that "human reasoning about matters of faith can stand in a twofold relationship to the believer's will." ${ }^{60}$ The first relationship refers to a person who has no willingness to believe due to lack of proof. In such a case "reasoning does take away from the merit of faith." The second relationship refers to reasoning that "can stand as something consequent upon the believer's willing", that is to say, when the believer seeks arguments in order to sustain the truth in which he believes. In this case "human reasoning does not take away the merit of faith, but is rather a sign of a greater merit." ${ }^{61} \mathrm{He}$ next delineates the role to be played by reason in support of the teaching and defence of the faith:

Arguments brought forth in support of the teaching of the faith are not demonstrations capable of leading the mind to clear understanding. The teaching of faith does not cease to be of things unseen. What arguments do is remove deterrents to faith, namely by showing that what is proposed for belief is not an impossibility. ${ }^{62}$

This latter argument is again brought up by Thomas within the context of apologetical argumentation in his De rationibus fidei contra Saracenos, Graecos et Armenos ad Cantorem Antiochenum. This work is a very short tract written in answer to a request made by an ecclesiastical official in Antioch in order to reply to objections posed mainly by Muslims concerning some principles of Christian belief and practice.

\footnotetext{
${ }^{59}$ Summa Theologiae, Ia, q. 1, art. 5 ad 2.

${ }^{60}$ Summa Theologiae, IIa IIae, q. 2 art. 10 reply.

${ }^{61}$ Ibid.

${ }^{62}$ Summa Theologiae, IIa IIae, q. 2 art. 10 ad 2.
} 
The chapters of this text are so structured because they are centred upon the exhortation of St. Peter (1 Pt. 3:15): "Parati semper ad satisfactionem omni poscenti vos rationem de ea quae in vobis est fide et spe" (Always be prepared to make a defence to any one who calls you to account for the faith and the hope that is in you). This text is quoted by Thomas in the first chapter of the treatise. Where the Greek text of the New Testament mentions only hope, Thomas's Vulgate has a variant reading which adds the virtue of faith. As Gilles Emery has observed, the version chosen by Thomas serves a particular purpose given that, for him, the Christian faith is contained above all in the confession of the Trinity and in the glorification of the Cross. These two articles of faith contain the entire body of Christian doctrine. ${ }^{63}$

He is concerned with laying particular emphasis on the Cross, which appears to have been the object of sarcasm among the Muslim interlocutors in Antioch. Furthermore, he wanted to demonstrate that faith in the humanity of Christ is inextricably linked to the profession of faith in the Cross.

As David Burrell remarks, in this short treatise Thomas does not demonstrate any wish whatsoever to engage in polemics. Instead, he takes the opportunity to present a brief summary of Christian doctrine concerning those points identified by the Cantor as being of particular importance to Muslims. He does not respond directly to the Muslim interlocutor. What he does is to furnish the Cantor with a series of strategies in order to formulate an instructive and robust response, that is to say, a response that would take as a starting point the objections raised by Muslims in order to come up with an insightful presentation of the heritage of the Christian faith. ${ }^{64}$ In undertaking this task Thomas teaches us that by taking as a point of departure the objections put forward by Muslims, one might find better ways to come up with a clearer exposition of the principles of the Christian faith.

Concerning any possible disputation with non-Christians, and in this particular case, with Muslims, he affirms that the Christian faith includes mysteries that lie beyond that which human reason is capable of grasping. From this premise, two conclusions are to be drawn. The first is that arguments drawn from human reason cannot prove the truth of the Christian faith, nor are they capable of convincing those who do not believe in it. For the Aquinas such a procedure would "belittle the sublimity of the Faith, whose truth exceeds not only human minds but also those of angels; we believe in them only because they are revealed by

${ }^{63}$ See Saint Thomas d'Aquin: Les raisons de la foi, Les Articles de la foi, et Les sacrements de l'Église, Introduction, Traduction du latin et annotation par G. Emery, Paris: Les Éditions du Cerf, 1999, p. 21f.

${ }^{64}$ This succinct description captures the modus procedendi of St. Thomas wherein apologetics also becomes dialogue. See D.B. Burrell C.S.C, "Thomas Aquinas and Islam," in Jim Fodor and Frederick Christian Bauerschmidt (eds.), Aquinas in Dialogue: Thomas for the Twenty-First Century, Malden, Minnesota: Blackwell Publishing, 2004, p. 82. 
God". ${ }^{65}$ The second conclusion is that Christians may refute their opponents' arguments by demonstrating that they are insufficient. In such a case, the duty of the Christian is not to furnish proofs for the Faith, but rather to defend it. ${ }^{66}$

The truths of the Faith lie well beyond the reach of the human mind. At this juncture Thomas turns the argument around and appeals to reason, which is necessary for the defence of the same faith, given that "whatever comes from the Supreme Truth cannot be false, and what is not false cannot be repudiated by necessary reason". In this manner "reason can show that what the Catholic Faith holds is not false." ${ }^{67}$

The latter argument is also found in the Summa Theologiae wherein Thomas introduces the question as to whether giving reasons for matters of faith lessens its merits. He replies that "human reasoning about matters of faith can stand in a twofold relationship to the believer's will." ${ }^{68}$ The first relationship refers to a person who has no willingness to believe due to lack of proof. In such a case "reasoning does take away from the merit of faith." The second relationship refers to reasoning that "can stand as something consequent upon the believer's willing", that is to say, when the believer seeks arguments in order to sustain the truth in which he believes. In this case "human reasoning does not take away the merit of faith, but is rather a sign of a greater merit." ${ }^{99}$ Having made his point Thomas then proceeds to articulate the role of reason in support of the teaching and the defence of the Faith:

Arguments brought forth in support of the teaching of faith are not demonstrations capable of leading the mind to clear understanding. The teaching of faith does not cease to be of things unseen. What these arguments do is remove deterrents to faith, namely by showing that what is proposed for belief is not an impossibility. ${ }^{70}$

Aquinas returns to this line of argumentation in the Summa contra Gentiles when he reaffirms the superiority of the Christian faith to the exercise of human reason:

[1] Now, although the truth of the Christian faith... surpasses the capacity of the reason, nevertheless that truth that the human reason is naturally endowed to know cannot be opposed to the truth of the Christian faith.

${ }^{65}$ De rationibus fidei contra Saracenos, Graecos et Armenos ad Cantorem Antiochenum, translated by J. Kenny, O.P. as "Reasons for the Faith against Muslim Objections," in Islamochristiana 22 (1996), pp. 31-52. The above quotation refers to chapter 2 of the work. All other quotations concerning this treatise are taken from the above-mentioned translation.

${ }^{66}$ See J. Waltz, "Muhammad and the Muslims in St. Thomas Aquinas," in The Muslim World, n. 66 (1976), pp. 90-91.

${ }^{67}$ De rationibus fidei, chapter 2.

${ }^{68}$ Summa Theologiae, IIa IIae, q. 2 art. 10 reply.

${ }^{69} \mathrm{Ibid}$.

${ }^{70}$ Summa Theologiae, IIa IIae, q. 2 art. 10 ad 2. 
For that with which the human reason is naturally endowed is clearly most true; so much so, that it is impossible for us to think of such truths as false. Nor is it permissible to believe as false that which we hold by faith, since this is confirmed in a way that is so clearly divine. Since, therefore, only the false is opposed to the true, as is clearly evident from an examination of their definitions, it is impossible that the truth of faith should be opposed to those principles that the human reason knows naturally. ${ }^{71}$

In addressing such delicate matters Aquinas continually emphasized the need for teachers to guide the faithful towards the truth. In addressing such delicate matters Aquinas continually emphasized the need for teachers to guide the faithful towards the truth. This is already clearly indicated in the theme he chose for his inaugural address on the occasion of his inception as Magister Sacrae Pagi$n a e^{72}$. This was provided by Psalm 103:13: Rigans montes de superioribus suis / de fructu operum tuorum satiabitur terra ("As you water the hills from your heights, the earth shall be furnished abundantly with the fruit of your works." $)^{73}$ Here his basic thesis was the principle derived from Pseudo-Dionysius, namely that divine providence determined that all higher gifts, both spiritual and corporeal, descend from the highest realm to the lowest by way of intermediaries. Just as the rains flow from above, water mountains and form rivers that flow and fertilize the land, so spiritual wisdom flows from God to the minds of listeners through the mediation of teachers. The latter should be detached from worldly matters and be elevated in their lives so as to enlighten the faithful by their teaching. The power of communication, however, belongs properly to God whereas teachers participate in this as ministers and servants of divine wisdom. The listeners, on the other hand, should be humble in receiving sacred doctrine, firm in discriminating right from wrong, and fruitful so as to propagate as many words of wisdom as possible from the few that they have heard. ${ }^{74}$

\section{Conclusion}

In light of the above one can now draw certain conclusions concerning both similarities and differences in the approach taken by Ibn Rušd and Thomas Aquinas.

From the standpoint of theology, the terminus a quo of both is essentially the same, namely the harmony between reason (in the Aristotelian sense) and re-

\footnotetext{
${ }^{71}$ Summa contra Gentiles, Book I, ch. 7, n. 1.

72 According to Weisheipl the actual ceremony took place sometime in April or May 1256. See Weisheipl, Friar Thomas of Aquino: His Life, Thought and Works, Washington, DC: Catholic University of America Press, 1983, p. 102.

${ }^{73}$ In quoting this verse I have referred to the Latin Vulgate used by Aquinas.

${ }^{74}$ Weisheipl, op. cit., pp. 102-103.
} 
vealed truth contained in Scripture. They both sought to integrate Aristotelian thought within their respective religious traditions. Both attempted such an approach in opposition to an academic milieu that was hostile to such an endeavour. Ibn Rušd had to combat his enemies at the court of the Almohad caliph Abu Yūsuf Ya'qūb (d. 1199) and suffered humiliation and temporary exile; his writings were publicly burned and his ideas were consigned to oblivion for the best part of seven hundred years. In fact, the true heirs of Ibn Rušd were the thirteenth century Scholastics. Aquinas, for his part faced condemnation of some of his teachings posthumously by the then Archbishop of Paris Étienne Tempier (d. 1279) in 1277, to say nothing of the condemnations of Robert Kilwardby (d. 1279) and John Pecham (d. 1292) as well as the criticisms of John Duns Scotus (d. 1308) and William of Occam (d. 1347).

They also had in common what Alain de Libera terms the theologia philosophorum, that is to say, theological science inasmuch as it is philosophical science about God and the separate substances as defined by Aristotle in his Metaphysics. ${ }^{75}$

However, it appears that in certain instances Ibn Rušd was much more of a radical than Aquinas as regards the role of philosophy. Here again, one must keep in mind that the question for the former was not the harmony between faith and reason but whether the study of philosophy was a legitimate exercise in Islam. For Ibn Rušd religion appealed to the masses by applying symbols, imagery and laws, whereas philosophy arrived at the truths of revealed Law through demonstration. Furthermore, he gives the impression that the truth of religion lies in its appeal to reason. He goes to great lengths in order to establish the existence of harmony between philosophy and religion, but he appears to take it in the sense of conformity of religion to the requirements of rational discourse. Nowhere does this hold more true than in his discussion of the literal (or 'apparent') and the allegorical (or 'inner') interpretation of the Qur'ân.

The method adopted by Aquinas is the inverse. For him revealed truth, that is to say the truth of the Christian faith, lies beyond reason, but the latter cannot be opposed to the former, since what nature endows cannot be opposed to supernatural gift. Furthermore, the exercise of reason is instrumental in order to clarify, corroborate and defend the truths of the Christian faith. Consequently, reason should be applied in order to prove that what adversaries are stating about the Christian faith is false and not to prove that the Christian faith is right. Although the realm of reason is not coextensive with that of faith, this by no means should imply that they are mutually exclusive or contradictory. As Aquinas points out, the philosopher considers creatures as they are, whereas the believer views them in their relation to God. ${ }^{76}$

\footnotetext{
${ }^{75}$ Alain de Libera in Averroès: L'islam et la raison, p. 34.
}

${ }^{76}$ Summa contra Gentiles, Book II, ch. 4, nn. 1-2. 
One must also keep in mind that Aquinas was capable of facing the multiple challenges posed by the academic environment of his time. This was due to his research of sources that went beyond those of the Christian tradition in order to broaden his philosophical and theological horizons.

At this point one may note with interest Aquinas's careful reading of the philosophical works, including those of Ibn Rušd, which contributed to the enrichment of his ideas and the solidity of his works. As David Burrell has so astutely observed, one need only glance at the strategic choices that he made when quoting such authorities as Moses Maimonides (d. 1204), Ibn Sīnā and the "Commentator" Ibn Rušd, whose works were vital in preserving and bequeathing the works of Aristotle to posterity. Aquinas's intellectual investigations allowed him to bridge the divide that arose in encounters with members of non-Christian religions in the common pursuit of truth. In this manner he strove to develop common perspectives concerning creation and divine providence as well as parallel approaches to the subject of attaining human perfection. His works are a living testimony to the encounter between Christian thought and Islamic philosophy inspired by both the Peripatetics and the Neoplatonists together with the indirect contribution of Muslim theological thought $(\mathrm{kalamm}) .^{77}$

\section{Summary}

The article by Joseph Ellul OP analyses similarities and differences in the philosophical approach of Ibn Rušd and St. Thomas Aquinas. For the Muslim philosopher, religion appealed to the masses by applying symbols, imagery and laws, whereas philosophy arrived at the truths of revealed Law through demonstration. He goes to great lengths in order to establish the existence of harmony between philosophy and religion, but he appears to take it in the sense of conformity of religion to the requirements of rational discourse, particularly in his discussion of the literal and the allegorical interpretation of the Qur'ân.

For Thomas Aquinas revealed truth, that is to say the truth of the Christian faith, lies beyond reason, but the latter cannot be opposed to the former, since what nature endows cannot be opposed to supernatural gift. The exercise of reason is instrumental in order to clarify, corroborate and defend the truths of the Christian faith. Consequently, reason should be applied in order to prove that what adversaries are stating about the Christian faith is false. Although the realm of reason is not coextensive with that of faith, this by no means should imply that they are mutually exclusive or contradictory. As Aquinas points out, the philosopher considers creatures as they are, whereas the believer views them in their relation to God.

Aquinas's intellectual investigations allowed him to bridge the divide that arose in encounters with members of non-Christian religions in the common pursuit of truth. His works are a living testimony to the encounter between Christian thought and Islamic philosophy inspired by both the Peripatetics and the Neoplatonists together with the indirect contribution of Muslim theological thought.

${ }^{77}$ See D.B. Burrell C.S.C., art. cit., p. 69. In this connection the author of the article also refers to the pioneering work undertaken by Louis Gardet in this area. Concerning the term kalâm, see supra n. 8 . 


\section{Streszczenie}

Artykuł Josepha Ellula analizuje podobieństwa i różnice w filozoficznej refleksji Ibn Rušda i Tomasza z Akwinu. Według muzułmańskiego filozofa, o ile religia odnosiła się ludzi poprzez zastosowane symbole, obrazy i prawa, o tyle filozofia ukazywała prawdę objawioną dzięki dowodzeniu. Dlatego usiłował on zachować harmonię między filozofią i religią, podkreślając zgodność religii z wymogami racjonalnego dyskursu, co szczególnie uwidoczniło się w jego dyskusji nad wyrazową i alegoryczną interpretacją Koranu.

Dla Tomasza z Akwinu prawda objawiona znajduje się poza rozumem, który nie może pozostawać do niej w opozycji. Wysiłek intelektualny pełni tutaj funkcję służebną: mając na celu wyjaśnianie, potwierdzanie i obronę prawd wiary chrześcijańskiej. W związku z tym dowody powinny być stosowane w celu wykazania, że to, co przeciwnicy twierdzą na temat wiary chrześcijańskiej, jest fałszywe. Mimo że sfera rozumu nie pokrywa się z domeną wiary, to w żaden sposób nie implikuje wzajemnego wykluczenia. Jak zauważa Akwinata, filozof rozważa stworzenia same w sobie, natomiast wierzący postrzega je w ich odniesieniu do Boga.

Refleksja Tomasza z Akwinu, ubogacona lekturą dzieł muzułmańskiego filozofa, umożliwiła mu spotkanie z reprezentantami religii niechrześcijańskich we wspólnym dążeniu do prawdy. Jego dzieła są świadectwem spotkania filozofii chrześcijańskiej oraz islamskiej inspirowanych zarówno przez perypatetyków i neoplatoników, jak i pośrednio przez muzułmańską myśl teologiczną.

\section{Keywords}

Religious discourse, Philosophy, Ibn Rušd, Thomas Aquinas, Scholasticism

\section{Słowa kluczowe}

dyskurs religijny, filozofia, Ibn Rušd, Tomasz z Akwinu, scholastyka

\section{Bibliography}

Alami Dawoud Sudqi El and Hinchcliffe Doreen, Islamic Marriage and Divorce Laws of the Arab World. London-The Hague-Boston: Kluwer Law International, 1996.

Alfarabi: Philosophy of Plato and Aristotle, translated with an introduction by Muhsin Mahdi (revised edition), Ithaca, New York: Cornell University Press, 2001.

Al-Ġazālī, Deliverance from Error and Mystical Union with the Almighty: Al-Munqidh min al-Dalāl, English translation with introduction by Muhammad Abūlayah, and Critical Arabic text established with Nurshīf Abdul-Rahīm Rif'at, Introduction and notes by George F. McLean, Washington, D.C.: The Council for Research in Values and Philosophy, 2001.

Al-Ġazālī, The Incoherence of the Philosophers, A parallel English-Arabic text translated, introduced, and annotated by Michael E. Marmura, Provo, Utah: Brigham Young University Press, 2002.

Averroës, The Decisive Treatise determining the Connection between the Law and Wisdom \& Epistle Dedicatory, Translation, with introduction and notes by Charles E Butterworth, Provo, Utah: Brigham Young University Press, 2008. 
Avicenna: The Metaphysics of “The Healing”, translated, introduced, and annotated by Michael E. Marmura, Provo, Utah: Brigham Young University Press, 2005.

Burrell D.B. C.S.C, Thomas Aquinas and Islam, in J. Fodor and F. Christian Bauerschmidt (eds.), Aquinas in Dialogue: Thomas for the Twenty-First Century, Malden, Minnesota: Blackwell Publishing, 2004, pp. 67-85.

Burrell D.B., C.S.C., "Aquinas and Islamic and Jewish Thinkers" in N. Kretzmann and E. Stump (eds.), The Cambridge Companion to Thomas Aquinas, Cambridge, UK: Cambridge University Press, 1993, pp. 60-83.

Chenu M-D, Aquinas and His Role in Theology, Collegeville, Minnesota: Michael Glazier, 2002.

Craig E., (Editor), Encyclopedia of Philosophy, London: Routledge, 1998.

Dante Alighieri, The Divine Comedy, The Inferno, the Purgatorio and the Paradiso, translated by J. Ciardi, New American Library, New York 2003.

Gardet L., "Saint Thomas et ses prédecesseurs arabes," in A. Maurer (ed.), St. Thomas Aquinas 1274-1974, Commemorative studies, Toronto: Pontifical Institute of Mediaeval Studies, 1974, vol. I, pp. 419-448.

Gilson É., Les sources gréco-arabes de l'augustinisme avicennisant, (Paris: Librairie Philosophique J. Vrin, 1986).

Habermas J., Ratzinger J., The Dialectics of Secularization: On Reason and Religion, (San Francisco, Ignatius Press 2007).

John Paul II, Fides et Ratio, Vatican City: Libreria Editrice Vaticana, 1998.

Kraemer J.L., Humanism in the Renaissance of Islam (Leiden: E.J. Brill, 1992).

Leaman O., Averroes and his philosophy (Richmond, Surrey: Curzon Press, 1998).

Libera A. de, Averroès: L'islam et la raison, traduction par M. Geoffroy, presentation par A. de Libera, Paris: GF Flammarion, 2000.

Plato: Complete Works, Edited, with Introduction and Notes, by John M. Cooper, Indianapolis/Cambridge, Massachusetts, Hackett Publishing Company, 1997.

Ṭabarī, Ğāmi al-bayān 'an ta'wīl ây al-Qur'ân, Mạ̣mūd Muḥammad Šakīr and Aḥmad Muhammad Šakīr (eds), Cairo: Dār al-Ma'ārif, 1374/1954-.

Taylor R.C., 'Averroes: religious dialectic and Aristotelian philosophical thought', Peter Adamson \& Richard C. Taylor R.C., The Cambridge Companion to Arabic Philosophy (Cambridge, UK: Cambridge University Press, 2005).

Thomas Aquinas, De rationibus fidei contra Saracenos, Graecos et Armenos ad Cantorem Antiochenum, translated by J. Kenny, O.P. as "Reasons for the Faith against Muslim Objections," in Islamochristiana 22 (1996), pp. 31-52.

Thomas Aquinas, Scriptum super libros Sententiarum magistri Petri Lombardi episcopi Parisiensis, t. 2, ed. P. Mandonnet, P. Lethielleux, Parisiis 1929.

Thomas Aquinas, Summa contra Gentiles, Book One: God, translated with an Introduction and Notes by A.C. Pegis, F.R.S.C., Notre Dame, Indiana: University of Notre Dame Press, 1975.

Thomas Aquinas, Summa Theologiae, English translation published by Blackfriars in conjunction with Eyre \& Spottiswoode, London and McGraw-Hill, New York, 1964-1966. 
Thomas d'Aquin, Saint: Les raisons de la foi, Les Articles de la foi, et Les sacrements de l'Église, Introduction, Traduction du latin et annotation par Gilles Emery (Paris: Les Éditions du Cerf, 1999).

Tocco de G., Vita Sancti Thomae Aquinatis, in Fontes Vitae S. Thomae Aquinatis (notis historicis et criticis illustrati), curis et labore D. Prümmer O.P., Fasciculus II, Tolosa s.d.

Waltz J., "Muhammad and the Muslims in St. Thomas Aquinas," in The Muslim World, n. 66 (1976), pp. 90-91

Weisheipl J.A., Friar Thomas of Aquino: His Life, Thought and Works, Washington, DC: Catholic University of America Press, 1983.

Zerafa P., O.P., “Alterità Mitologika u Alterità Filosofika," in KNISJA 2000, n. 21 (1992), pp. 14-15. 